\title{
The effect of feeding canola meal on concentrations of plasma amino acids
}

\author{
R. Martineau, D. R. Ouellet, and H. Lapierre ${ }^{1}$ \\ Dairy and Swine Research and Development Centre, Agriculture and Agri-Food Canada, Sherbrooke, Quebec, Canada J1M 0C8
}

\begin{abstract}
An initial meta-analysis on isonitrogenous experiments where a protein source was replaced by canola meal (CM) showed that CM feeding increased yields of milk and milk protein and apparent $\mathrm{N}$ efficiency. The objective of the current study was to determine if these responses were related to increased changes in plasma AA concentrations. Although only half of the experiments of the initial meta-analysis reported concentrations of plasma AA and could be used in the current meta-analysis, lactational responses to $\mathrm{CM}$ feeding were similar to those reported previously. In the current meta-analysis, CM feeding increased plasma concentrations of total AA, total essential AA (EAA) and all individual EAA, but decreased concentrations of blood and milk urea-N. The current meta-analysis suggests that CM feeding increased the absorption of EAA, which would be responsible for the increased milk protein secretion and the increased apparent $\mathrm{N}$ efficiency.
\end{abstract}

Key words: amino acid, canola meal, metabolizable protein, blood urea-N

\section{INTRODUCTION}

Two meta-analyses were recently published to evaluate the production responses to canola meal (CM) feeding in dairy cows. Huhtanen et al. (2011) compared mostly separate experiments where different proportions of either $\mathrm{CM}$ or another protein source were fed at different rates in the diet (i.e., 2 or more dietary $\mathrm{CP}$ concentrations). In contrast, Martineau et al. (2013) examined the effects of CM feeding when $\mathrm{CM}$ replaced another protein source in isonitrogenous rations (i.e., in the same experiment). Although different methodologies and databases were used in these meta-analyses, the inclusion of $\mathrm{CM}$ in dairy rations increased yields of milk and milk protein. In addition, some concerns were expressed about the accuracy of MP estimations from NRC (2001) in both meta-analyses. Huhtanen et al. (2011) reported that milk protein yield (MPY) was

Received June 12, 2013.

Accepted November 24, 2013

${ }^{1}$ Corresponding author: Helene.Lapierre@agr.gc.ca better predicted by $\mathrm{CP}$ intake compared with estimated MP supply ( $\left.\mathbf{M P}_{\text {supply }}\right)$ based on the residual variance and the variability of the random slope. Martineau et al. (2013) reported that CM feeding decreased estimated $\mathrm{MP}_{\text {supply }}$ but increased MPY, suggesting that $\mathrm{MP}_{\text {supply }}$ was underestimated when CM was fed to dairy cows because $\mathrm{MP}_{\text {supply }}$ is a key factor that determines milk protein secretion (NRC, 2001; Broderick et al., 2010).

The hypothesis of the current meta-analysis was that the increased MPY observed with CM inclusion in dairy rations was associated with a concomitant increase in plasma AA concentrations. Therefore, the main objective of the study was to determine the effect of CM feeding on plasma AA concentrations through a meta-analysis. In addition, another objective was to evaluate the changes in estimated $\mathrm{MP}_{\text {supply }}$ and digestible flows of each EAA with CM feeding.

\section{MATERIALS AND METHODS}

The database used in the current meta-analysis included the experiments from the initial meta-analysis (Martineau et al., 2013) that reported plasma or serum AA concentrations. Plasma AA concentrations were reported in most experiments, except Laarveld and Christensen (1976) and Piepenbrink et al. (1998); therefore, "plasma" will be used for "plasma or serum" AA concentrations hereafter. The database also included the isonitrogenous experiments of Choi et al. (2002) and Vanhatalo et al. (2004). These experiments were not included in Martineau et al. (2013) because $\mathrm{CM}$ was compared with protein sources highly soluble in the rumen (Choi et al., 2002) and field peas (Pisum sativum L.; Vanhatalo et al., 2004), a protein source not commonly fed to dairy cows (NRC, 2001). However, given the scarcity of isonitrogenous experiments reporting concentrations of plasma AA, Choi et al. (2002) was included because soluble NAN flows entering the omasal canal did not differ between protein sources, suggesting that a considerable proportion of free AA, peptides, and proteins in the liquid phase of digesta escaped ruminal degradation. Vanhatalo et al. (2004) was also included because field peas contain $24 \%$ CP (DM basis; INRA, 2007) and meet the minimal CP threshold set for a protein supplement in Martineau et al. (2013). 
Because the number of studies available for the current meta-analysis was more limited compared with the initial meta-analysis, diets were defined as isonitrogenous if the difference in $\mathrm{CP}$ concentration between control and CM diets did not exceed 1.5\% (DM basis; instead of $1.0 \% \mathrm{CP}$, as set in the initial meta-analysis). This small difference allowed the inclusion of the comparison between $\mathrm{CM}$ and soybean meal (SBM) from Oba et al. (2010). Some AA data in Christen et al. (2010) were corrected by inverting reported values of Asn for Asp and Glu for Gln (D. Schingoethe, South Dakota State University, Brookings, personal communication). Overall, the database included 21 experiments reported in 10 studies (Table 1 ).

As in Martineau et al. (2013), responses included DMI, yields of milk (MY) and ECM (Sjaunja et al., 1990) in kilograms per day; percentages of milk protein, fat, and lactose; yields of milk protein, fat, and lactose in grams per day; efficiency of milk production (i.e., ECM/DMI) in kilograms per kilogram; and apparent $\mathrm{N}$ efficiency (i.e., $\mathrm{N}$ in milk/ $\mathrm{N}$ intake) in grams per kilogram. Specifically for the current meta-analysis, responses included plasma concentrations of individual AA, branched-chain AA (BCAA; Ile, Leu, and Val), urea cycle AA (Arg, Cit, and Orn), total EAA and NEAA in micromolar concentrations, BUN and MUN (both in millimolar concentrations). In addition, responses also included estimated flows of MP and digestible individual EAA in grams per day (NRC, 2001).

The methodology used in the current study was similar to that reported in Martineau et al. (2013). Briefly, all regressions were conducted on responses or changes $(\Delta$ : the value from the $\mathrm{CM}$ diet minus the value from the control diet), forced through the origin (no intercept in the model), and weighted by sample size. Regressions were forced through the origin because responses were assumed to be zero when CM intake was zero (Glasser et al., 2008; Martineau et al., 2013). Besides changes in dietary concentration of $\mathrm{CP}$ between $\mathrm{CM}$ and control diets, regressions also included changes in DMI as a covariate in the model. Only the effect of the dietary proportion of CM expressed as $100 \mathrm{~g} / \mathrm{kg}$ (DM basis) is reported in the current meta-analysis; therefore, the coefficient of $\mathrm{CM}$ was the response expected for each increment of 1 unit of $10 \%$ inclusion of $\mathrm{CM}$ in the ration (e.g., $2 \mathrm{~kg}$ of $\mathrm{CM}$ per $20 \mathrm{~kg}$ of DMI) in models controlling for variations in DMI and in dietary concentration of $\mathrm{CP}$. The effect of qualitative factors (e.g., type of forage and protein source or treatment of canola) could not be tested with accuracy in the current meta-analysis because of the limited number of observations.

The range of inference for this meta-analysis is limited to the domain of the specific experiments in the

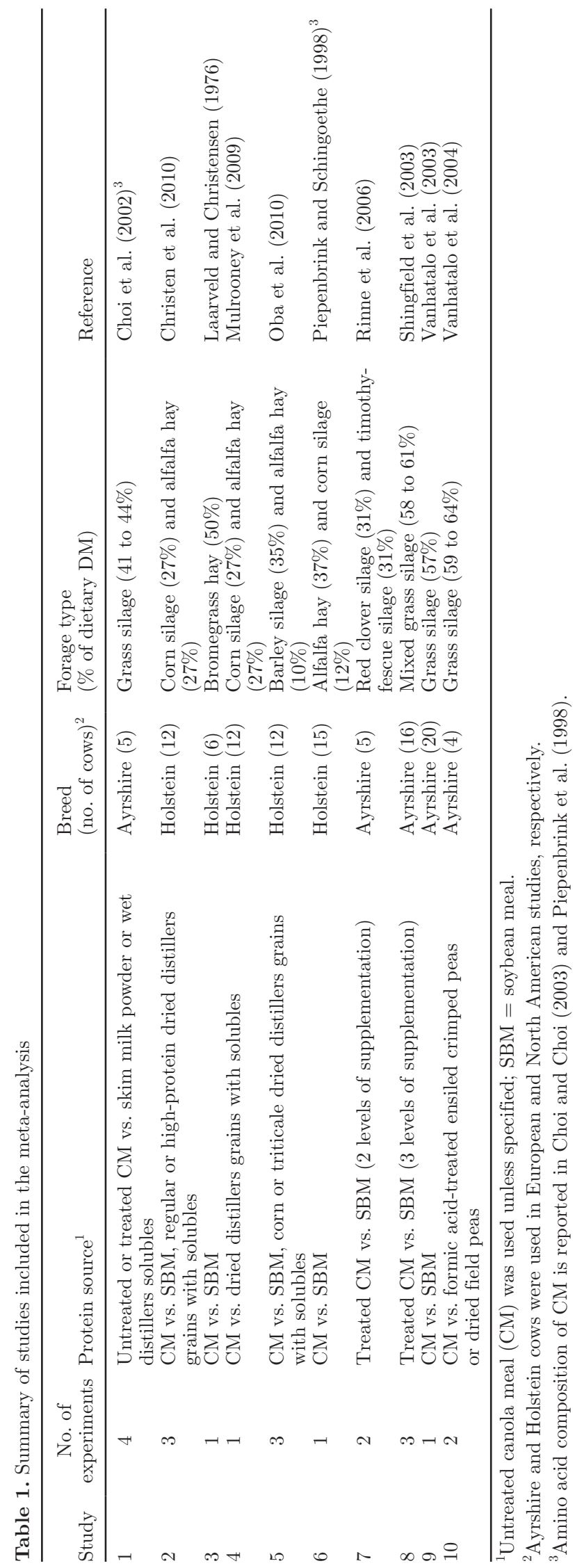


Table 2. Descriptive statistics of protein source and canola meal (CM) intakes, dietary proportion of CM and $\mathrm{CP}$ in control $(\mathrm{Ctrl})$ and $\mathrm{CM}$ diets, and the difference between diets $(\Delta ; \mathrm{CM} \text { minus } \mathrm{Ctrl})^{1}$

\begin{tabular}{lllcccc}
\hline Variable $^{2}$ & Diet & $\mathrm{n}^{3}$ & Mean & $\mathrm{SD}$ & Minimum & Maximum \\
\hline Protein source intake $(\mathrm{kg} / \mathrm{d})$ & $\mathrm{Ctrl}$ & 21 & 2.59 & 1.104 & 0.66 & 5.00 \\
& $\mathrm{CM}$ & 21 & 2.41 & 0.749 & 1.04 & 3.37 \\
& $\Delta$ & 21 & -0.164 & 0.919 & -1.803 & 1.104 \\
$\mathrm{CM}$ intake $(\mathrm{kg} / \mathrm{d})$ & $\mathrm{Ctrl}$ & 21 & 0.00 & 0.000 & 0.00 & 0.00 \\
& $\mathrm{CM}$ & 21 & 2.40 & 0.745 & 1.04 & 3.34 \\
$\mathrm{CM}$ proportion $(100 \mathrm{~g} / \mathrm{kg}, \mathrm{DM}$ basis $)$ & $\Delta$ & 21 & 2.403 & 0.745 & 1.044 & 3.341 \\
& $\mathrm{Ctrl}$ & 21 & 0.00 & 0.000 & 0.00 & 0.00 \\
$\mathrm{CP}(\%$, DM basis $)$ & $\mathrm{CM}$ & 21 & 1.07 & 0.267 & 0.51 & 1.54 \\
& $\Delta$ & 21 & 1.071 & 0.267 & 0.507 & 1.539 \\
& $\mathrm{Ctrl}$ & 21 & 16.76 & 1.469 & 14.42 & 19.66 \\
& $\mathrm{CM}$ & 21 & 16.97 & 1.681 & 13.92 & 20.00 \\
& $\Delta$ & 21 & 0.206 & 0.550 & -0.537 & 1.500 \\
\hline
\end{tabular}

${ }^{1} \Delta=\mathrm{CM}$ diet mean minus Ctrl diet mean. A positive value represents an increase in response to CM and a negative value indicates a decrease.

${ }^{2}$ Protein source was defined as a concentrated feed containing at least $20 \% \mathrm{CP}$ (DM basis).

${ }^{3}$ Overall, the database included 33 different treatment means that generated 21 pairs of Ctrl and CM treatments.

data set because the experimental conditions were not randomly distributed and were specific to each study (Sauvant et al., 2008). Therefore, experiment was considered as a fixed factor in the models and all statistical analyses were conducted using the GLM procedure of Minitab (version 16.1.1.0, 2010; Minitab Inc., State College, PA). The project was submitted to and approved by the Institutional Committee for Animal Care of the Sherbrooke Research Centre (Sherbrooke, QC, Canada), although no animals were required for this study.

\section{RESULTS}

Hereafter, "response to the substitution of a protein source by CM" will be referred more conveniently to as "CM feeding." Overall, the daily intake of CM did not exceed $3.34 \mathrm{~kg} /$ cow and averaged $10.7 \%$ of total DMI without exceeding $15.4 \%$ (Table 2). Responses in DMI were mostly positive (all except 3 ) and increased $(P$ $<0.001$ ) by $0.43 \mathrm{~kg} / \mathrm{d}$ for each $10 \%$ of $\mathrm{CM}$ inclusion in the ration (Table 3). Responses in MY were mostly positive (all except 2$)$ and increased $(P<0.001)$ by $0.74 \mathrm{~kg} / \mathrm{d}$ for each $10 \%$ of $\mathrm{CM}$ inclusion in the ration (Table 3). Canola meal feeding increased milk protein percentage $(+0.02 \%$ for each $10 \%$ of $\mathrm{CM}$ inclusion) but the effect did not reach significance $(P=0.14)$; on the other hand, CM feeding decreased $(P=0.05)$ responses in milk fat percentage $(-0.08 \%$ for each $10 \%$ of CM inclusion). Canola meal feeding did not affect $(P=0.29)$ responses in milk lactose percentage. As a result, $\mathrm{CM}$ feeding increased $(P<0.001)$ responses in MPY and milk lactose yield (MLY) by +30 and $+39 \mathrm{~g} / \mathrm{d}$, respectively, for each $10 \%$ of $\mathrm{CM}$ inclusion in the ration (Table 3$)$. Canola meal feeding tended $(P$
$=0.10)$ to increase the efficiency of milk production and increased $(P<0.01)$ the responses in apparent $\mathrm{N}$ efficiency (Table 3). Responses in MUN were negatively associated $(P<0.01)$ with $\mathrm{CM}$ feeding (Table 3$)$ and tended to be negatively correlated with responses in apparent $\mathrm{N}$ efficiency $(\mathrm{r}=-43 \% ; P=0.08)$.

Plasma concentrations of total AA, total EAA, BCAA, urea cycle AA, and all individual EAA responded positively to CM feeding $(P \leq 0.10$; Table 4$)$. On the other hand, CM feeding decreased $(P<0.001)$ BUN concentrations (Table 4). All responses in BUN, except 1 , were negative and strongly correlated with responses in MUN ( $\mathrm{r}=82 \% ; P<0.001)$. Canola meal feeding had no effect on responses in plasma concentrations $(\mu M)$ of total NEAA and most individual NEAA, except Cys, Orn, and Ser: $+0.9 \pm 0.47(P=0.10) \times$ $\mathrm{CM}\left(\mathrm{R}^{2}=80 \% ; \mathrm{n}=10\right),+3.7 \pm 1.22(P=0.01) \times \mathrm{CM}$ $\left(\mathrm{R}^{2}=43 \% ; \mathrm{n}=13\right)$, and $-4.5 \pm 2.02(P=0.04) \times \mathrm{CM}$ $\left(\mathrm{R}^{2}=22 \% ; \mathrm{n}=18\right)$, respectively.

Estimated $\mathrm{MP}_{\text {supply }}$ averaged 2,022 ( $\left.\mathrm{SD}=512.0\right)$ and 2,067 $(\mathrm{SD}=450.4) \mathrm{g} / \mathrm{d}$ in control and $\mathrm{CM}$ diets, respectively. Changes in estimated MP supply (g/d) resulting from $\mathrm{CM}$ feeding (i.e., $\Delta \mathrm{MP}_{\text {supply }}$ ) tended to be positively associated with CM feeding: $+31.7 \pm 17.74$ $(P=0.09) \times \mathrm{CM}\left(\mathrm{R}^{2}=16 \% ; \mathrm{n}=21\right)$. Canola meal feeding had no effect on changes in estimated digestible supplies $(\mathrm{g} / \mathrm{d})$ of most EAA, except Met and Thr: +0.8 $\pm 0.32(P=0.03) \times \mathrm{CM}\left(\mathrm{R}^{2}=71 \% ; \mathrm{n}=20\right)$ and $+1.9 \pm 0.68(P=0.01) \times \mathrm{CM}\left(\mathrm{R}^{2}=74 \% ; \mathrm{n}=21\right)$, respectively. Accordingly, the proportions (\%) of Met and Thr in estimated $\mathrm{MP}_{\text {supply }}$ responded positively to CM feeding: $+0.04 \pm 0.009(P<0.01) \times \mathrm{CM}\left(\mathrm{R}^{2}=\right.$ $53 \% ; \mathrm{n}=21)$ and $+0.09 \pm 0.024(P<0.01) \times \mathrm{CM}\left(\mathrm{R}^{2}\right.$ $=41 \% ; \mathrm{n}=21)$, respectively. In contrast to Met and Thr, the proportions (\%) of Leu and Phe in estimated 
Table 3. Responses ( $\pm \mathrm{SE}$ in parentheses) of DMI, lactational parameters, and MUN to substitution of a protein source by canola meal $(\mathrm{CM})^{1}$

\begin{tabular}{llcc}
\hline Response $^{2}$ & Term $^{3}$ & $\mathrm{R}^{2}(\%)$ & $\mathrm{n}$ \\
\hline$\Delta$ DMI $(\mathrm{kg} / \mathrm{d})$ & $+0.43^{* * *}( \pm 0.100) \times \mathrm{CM}$ & 48 & 21 \\
$\Delta$ MY $(\mathrm{kg} / \mathrm{d})$ & $+0.74^{* * *}( \pm 0.176) \times \mathrm{CM}$ & 47 & 21 \\
$\Delta$ MPY (g/d) & $+30.4^{* * *}( \pm 5.93) \times \mathrm{CM}$ & 57 & 21 \\
$\Delta$ MFY (g/d) & $\mathrm{NS}$ & 45 & 21 \\
$\Delta$ MLY (g/d) & $+38.9^{* * *}( \pm 10.21) \times \mathrm{CM}$ & 30 & 21 \\
$\Delta \mathrm{ECM} / \mathrm{DMI}(\mathrm{kg} / \mathrm{kg})$ & $+0.015 \dagger( \pm 0.009) \times \mathrm{CM}$ & 57 & 21 \\
$\Delta$ Milk N/N intake $(\mathrm{g} / \mathrm{kg})$ & $+7.9^{* *}( \pm 2.52) \times \mathrm{CM}$ & 52 & 17 \\
$\Delta$ MUN $(\mathrm{m} M)$ & $-0.42^{* *}( \pm 0.132) \times \mathrm{CM}$ & \\
\hline
\end{tabular}

${ }^{1}$ Responses were tested within experiment by forcing the regression through the origin (no intercept). Regressions were weighted by sample size and controlled for differences in DMI and dietary concentration of CP. Only the coefficients of $\mathrm{CM}$ with $P \leq 0.10$ are presented.

${ }^{2} \Delta=\mathrm{CM}$ diet mean minus control diet mean. MY = milk yield; MPY = milk protein yield; MFY $=$ milk fat yield; MLY = milk lactose yield.

${ }^{3} \mathrm{CM}=$ dietary proportion of $\mathrm{CM}(100 \mathrm{~g} / \mathrm{kg}$, DM basis); the coefficient of CM represents the response associated with an increment of $10 \% \mathrm{CM}$ in the diet (DM basis). NS: $P>0.10$.

${ }^{* * *} P \leq 0.001 ; * * P \leq 0.01 ; \dagger P \leq 0.10$.

$\mathrm{MP}_{\text {supply }}$ responded negatively to $\mathrm{CM}$ feeding: $-0.14 \pm$ $0.031(P<0.01) \times \mathrm{CM}\left(\mathrm{R}^{2}=50 \% ; \mathrm{n}=21\right)$ and -0.07 $\pm 0.009(P<0.01) \times \mathrm{CM}\left(\mathrm{R}^{2}=76 \% ; \mathrm{n}=21\right)$.

\section{DISCUSSION}

The current meta-analysis included experiments in which CM replaced another protein source in isonitrogenous rations and in which plasma or serum concentrations of AA were reported. Few experiments reported the effects of CM feeding on plasma concentrations of $\mathrm{AA}$; therefore, the isonitrogenous criterion used in the current meta-analysis was increased by $+0.5 \% \mathrm{CP}$ (DM basis) compared with the initial meta-analysis (Martineau et al., 2013), thus allowing the inclusion of 1 additional experiment. Note that raising the isonitrogenous criterion was under control because differences in CP concentration between CM and control diets were included in the models as a covariate. Even though they represent less than half the experiments used in the

Table 4. Responses ( \pm SE in parentheses) of plasma AA and BUN concentrations to substitution of a protein source by canola meal $(\mathrm{CM})^{1}$

\begin{tabular}{llcc}
\hline Response $^{2}$ & Term $^{3}$ & $\mathrm{R}^{2}(\%)$ & $\mathrm{n}$ \\
\hline$\Delta$ Total AA $(\mu M)$ & $+123.4^{*}( \pm 43.95) \times \mathrm{CM}$ & 31 & 21 \\
$\Delta$ Total NEAA $(\mu M)$ & $\mathrm{NS}$ & 47 & 21 \\
$\Delta$ Total EAA $(\mu M)$ & $+115.5^{* * *}( \pm 29.18) \times \mathrm{CM}$ & 21 \\
$\Delta$ BCAA $(\mu M)$ & $+67.6^{* *}( \pm 23.06) \times \mathrm{CM}$ & 35 & 20 \\
$\Delta$ Urea cycle AA $(\mu M)$ & $+9.3^{* *}( \pm 2.99) \times \mathrm{CM}$ & 47 & 12 \\
Individual EAA $(\mu M)$ & $+10.0^{* * *}( \pm 2.36) \times \mathrm{CM}$ & 54 & 18 \\
$\Delta$ Arg & $+5.3 \dagger( \pm 2.81) \times \mathrm{CM}$ & 20 & 19 \\
$\Delta$ His & $+14.9^{* *}( \pm 4.95) \times \mathrm{CM}$ & 37 & 18 \\
$\Delta$ Ile & $+17.0 \dagger( \pm 9.04) \times \mathrm{CM}$ & 30 & 18 \\
$\Delta$ Leu & $+6.5^{*}( \pm 2.27) \times \mathrm{CM}$ & 32 & 18 \\
$\Delta$ Lys & $+3.0^{* *}( \pm 0.82) \times \mathrm{CM}$ & 48 & 18 \\
$\Delta$ Met & $+3.9 \dagger( \pm 1.90) \times \mathrm{CM}$ & 30 & 18 \\
$\Delta$ Phe & $+10.8^{* *}( \pm 2.92) \times \mathrm{CM}$ & 49 & 18 \\
$\Delta$ Thr & $+2.8^{* *}( \pm 0.92) \times \mathrm{CM}$ & 36 & 17 \\
$\Delta$ Trp & $+25.8^{*}( \pm 10.15) \times \mathrm{CM}$ & 29 & 18 \\
$\Delta$ Val & $-0.81^{* * *}( \pm 0.142) \times \mathrm{CM}$ & 70 & 16 \\
$\Delta$ BUN $(\mathrm{m} M)$ & & & \\
\hline
\end{tabular}

${ }^{1}$ Responses were tested within experiment by forcing the regression through the origin (no intercept). Regressions were weighted by sample size and controlled for differences in DMI and dietary concentration of CP. Only the coefficients of CM with a $P$-value $\leq 0.10$ are presented.

${ }^{2} \Delta=\mathrm{CM}$ diet mean minus control diet mean; $\mathrm{NEAA}=$ nonessential $\mathrm{AA}$; $\mathrm{EAA}=$ essential $\mathrm{AA}$; $\mathrm{BCAA}=$ branched-chain AA; urea cycle AA $=\mathrm{Arg}+\mathrm{Cit}+$ Orn .

${ }^{3} \mathrm{CM}=$ dietary proportion of CM (100 g/kg, DM basis); the coefficient of CM represents the response associated with an increment of $10 \% \mathrm{CM}$ in the diet (DM basis). NS: $P>0.10$.

${ }^{* * *} P \leq 0.001 ;{ }^{* *} P \leq 0.01 ;{ }^{*} P \leq 0.05 ; \dagger P \leq 0.10$. 
meta-analysis of Martineau et al. (2013), meta-designs based on descriptive statistics and lactational responses appear similar in both studies. As reported in the initial meta-analysis, DMI responded positively to CM feeding; therefore, models were duly controlled for variations in DMI. As suggested by Huhtanen et al. (2011), DMI could increase in response to a greater energy demand due to the improved lactational performance when CM is included in the ration. Canola meal feeding increased MY, MPY, the efficiency of milk production, and the apparent $\mathrm{N}$ efficiency in the initial (Martineau et al., 2013) and current meta-analyses (Table 3). Responses in milk protein concentration were numerically similar to those obtained in the initial meta-analysis (i.e., $+0.02 \%$ ), but the effect did not reach significance in the current study in contrast with Martineau et al. (2013). This lack of significance may have resulted from the smaller number of data available in the current study. Furthermore, it should also be pointed out that, among lactational responses, the coefficient of determination was the lowest in terms of responses in milk protein concentration in Martineau et al. (2013).

Canola meal feeding decreased concentrations of milk lactose, especially when cows were supplemented with protein sources other than SBM or when cows were fed corn or barley silage alone or mixed with a similar proportion of grass or legume forage in Martineau et al. (2013). In the current meta-analysis, CM feeding had no effect on concentrations of milk lactose, probably because these protein sources and forages were used in fewer experiments compared with the initial metaanalysis (Table 1). Consequently, CM feeding increased MLY in the current study, although it did not in the initial meta-analysis.

The concomitant increases in MY, MPY, and MLY (Table 3) are in line with strong phenotypic correlations between MY and MPY and MLY (94 and 99\%, respectively) and between MPY and MLY (92\%), as reported by Miglior et al. (2007). Lactose maintains the osmolarity of milk (Cant et al., 2002), which explains the strong positive correlation between MY and MLY. Indeed, glucose is the main precursor of lactose synthesis in mammary gland epithelial cells, as more than $85 \%$ of the lactose originates from glucose (Bickerstaffe et al., 1974). Glucose synthesis could be stimulated by a greater DMI (response about twice larger in the current study than in initial meta-analysis (i.e., +0.43 vs. +0.24 ; Martineau et al., 2013) or by increased gluconeogenesis from AA supplied in excess. Lapierre et al. (2010) reported that MLY increases when the whole-body rate of appearance of glucose increases due to enhanced protein, but not to increased energy supply, suggesting that glucose itself was not the driving force behind lactose synthesis. The authors hypothesized that some
EAA were probably required to stimulate milk protein synthesis, either as constituents of protein per se or by playing a key role in specific metabolic pathways (e.g., activation of the mammalian target of rapamycin signaling cascade; Burgos et al., 2010). Canola meal feeding stimulated milk protein synthesis and increased apparent $\mathrm{N}$ efficiency in the current study. These effects were accompanied by lower concentrations of urea- $\mathrm{N}$, either as MUN or BUN (Tables 3 and 4), suggesting an improved whole-body $\mathrm{N}$ utilization efficiency by the animal and that more dietary protein was utilized to synthesize milk protein (Broderick et al., 2008).

Canola meal feeding increased plasma concentrations of total AA, total EAA, BCAA, and all individual EAA (Table 4). More than $90 \%$ of the increment in plasma total AA concentration originated from changes in plasma total EAA concentration, as CM feeding had no effect on plasma concentrations of total NEAA (Table 4). Although CM feeding induced a positive response on plasma concentrations of all EAA, results should be interpreted with caution because the coefficients of determination are relatively modest $(<54 \%$; Table 4$)$ due to the various experimental conditions and the small number of experiments available $(\mathrm{n}<21)$. Indeed, $\mathrm{CM}$ feeding increased OM intake (data not presented) and probably microbial protein synthesis because both are positively related (Clark et al., 1992). Therefore, the effect on feed intake might have played a role on the responses in plasma concentrations of EAA. However, as mentioned above, regression models were controlled for differences in DMI between CM and control diets; therefore, results of CM feeding are considered to be at similar DMI (and OM intake). Few studies reported the effect of $\mathrm{CM}$ feeding in isonitrogenous diets and include direct measurements of microbial synthesis (e.g., omasal digesta flow studies). At similar DMI and $\mathrm{N}$ intake, Brito et al. (2007) reported no difference in total microbial NAN flows at the omasal canal $(\mathrm{g} / \mathrm{d}$ and $\%$ of total NAN) between solvent-extracted SBM and CM supplementation. No difference was reported in omasal flows of AA but, unfortunately, plasma AA concentrations were not reported in Brito et al. (2007).

Canola meal feeding had marginal effects on plasma concentrations of some individual NEAA (i.e., Cys, Ser, and Orn). The positive effect of CM feeding on plasma concentrations of Cys might be related to its positive effect on plasma concentrations of Met because Cys may result from the catabolism of Met (Baker, 1994); indeed, plasma concentrations of Cys increased following Met supplementation (Pisulewski et al., 1996). Plasma concentrations of some NEAA can decrease due to their utilization for hepatic gluconeogenesis (e.g., Gln, Gly, and Ser; Miettinen and Huhtanen, 1997). In the current study, CM feeding decreased plasma concentrations of 
Ser but the effect on glucose did not reach significance, as glucose was reported in only 8 experiments (data not presented). Canola meal feeding increased plasma concentrations of Orn and urea cycle AA (i.e., Arg + Cit + Orn), suggesting that hepatic ureagenesis was stimulated. Yet, these results are difficult to reconcile with the negative effect of CM feeding on BUN and MUN concentrations (Tables 3 and 4). Indeed, increased BUN and MUN concentrations are associated with greater ruminal protein degradability or postruminal protein supply, or both, due to increased absorption of ruminal $\mathrm{NH}_{3}-\mathrm{N}$ and oxidation of $\mathrm{AA}$ absorbed in excess of requirements, respectively (Nousiainen et al., 2004). Few responses in ruminal $\mathrm{NH}_{3}-\mathrm{N}$ were available in the studies used in the current meta-analysis. Although not significant, results suggest a negative relationship between ruminal $\mathrm{NH}_{3}-\mathrm{N}(\mathrm{m} M)$ and $\mathrm{CM}$ feeding: -0.27 $\pm 0.296(P=0.39) \times \mathrm{CM}\left(\mathrm{R}^{2}=0.64 ; \mathrm{n}=9\right)$, in line with lower MUN and BUN concentrations. Hepatic AA oxidation probably increased with CM feeding, as indicated by greater concentration of plasma ureacycle AA and lower plasma Ser concentrations, which would suggest stimulated gluconeogenesis. However, the increased AA oxidation was probably not sufficient to elevate BUN and MUN concentrations in CM compared with control diets. Indeed, providing more AA to the animal does not always increase BUN or MUN concentrations. For example, Appuhamy et al. (2011) reported that the supplementation of a corn-based diet with Met and Lys $(12$ and $21 \mathrm{~g} / \mathrm{d}$, respectively, total jugular infusate) increased significantly MPY with no effect on MUN concentrations. However, adding BCAA $(60 \mathrm{~g} / \mathrm{d})$ to the jugular infusate did not increase MPY further but decreased MUN concentrations, suggesting that BCAA infusion promoted the synthesis of other body tissue proteins rather than increased AA catabolism. Another hypothesis is that a larger proportion of synthesized urea could be recycled back to the digestive tract and captured by ruminal microflora when cows are fed CM compared with other protein sources, but this hypothesis remains speculative for the moment.

The positive effect of CM feeding on concentrations of plasma EAA (Table 4; Figure 1) strongly suggests that CM feeding increased the absorption of AA. Indeed, Raggio (2006) demonstrated that increasing the flows of digestible AA increases the plasma concentrations of all EAA; therefore, the positive effects of CM feeding on plasma AA concentrations could be related to positive effects on postruminal protein supply and provision of digestible AA. Canola meal feeding did not increase omasal NAN flows ( $\mathrm{g} / \mathrm{d}$ or $\%$ of $\mathrm{N}$ intake) in Brito et al. (2007), but omasal NAN flows (g/d) were higher for CM compared with peas in Vanhatalo et al. (2004). More studies are needed to assess the effects of

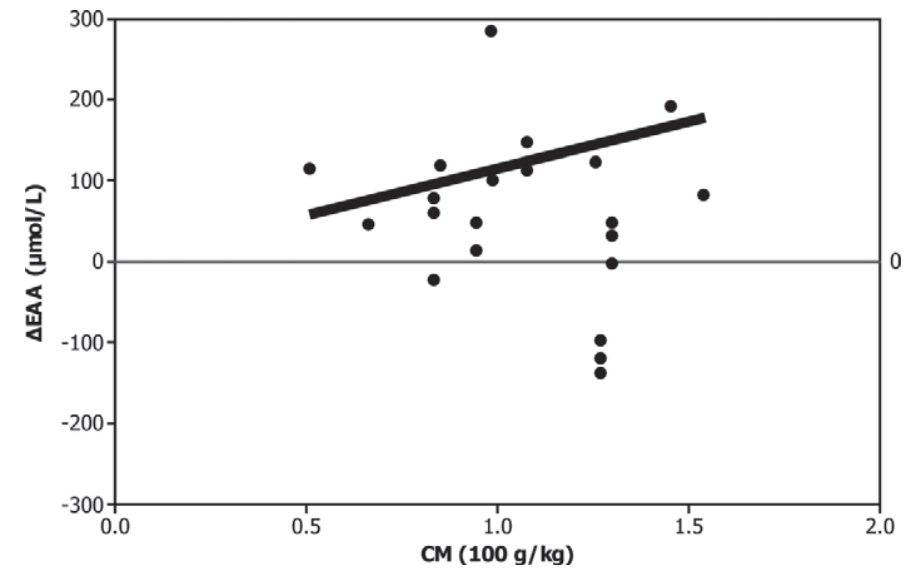

Figure 1. Positive relationship between responses of plasma total essential AA $(\mathrm{EAA})$ concentrations $(\triangle \mathrm{EAA}=$ canola meal diet minus control diet; $\mu M$ ) and substitution of a protein source by canola meal (CM; $100 \mathrm{~g} / \mathrm{kg}$, DM basis) when controlling for variations in DMI $(\triangle \mathrm{DMI} ; \mathrm{kg} / \mathrm{d})$ and in dietary concentration of $\mathrm{CP}(\triangle \mathrm{CP} ; \% \mathrm{DM}$ basis $): \Delta \mathrm{EAA}=115 \pm 29.2(P<0.01) \times \mathrm{CM}-107 \pm 43.4(P=0.02)$ $\times \Delta \mathrm{DMI}-79 \pm 44.0(P=0.09) \times \Delta \mathrm{CP}\left(\mathrm{R}^{2}=47 \% ; \mathrm{n}=21\right)$.

CM feeding on postruminal protein supply and plasma EAA concentrations, especially in North American or corn silage-based diets.

In the current meta-analysis, CM feeding tended to be positively associated with changes in estimated MP supply (i.e., $\Delta \mathrm{MP}_{\text {supply }}$ ), in line with positive responses in plasma total AA concentration and MPY. The positive relationship between $\mathrm{CM}$ feeding and $\triangle \mathrm{MP}-$ supply is in contrast with results reported in the initial meta-analysis where $\mathrm{CM}$ feeding reduced $\Delta \mathrm{MP}_{\text {supply, }}$ albeit increasing MPY (Martineau et al., 2013). The scatterplot of $\triangle \mathrm{MPY}$ and $\Delta \mathrm{MP}_{\text {supply }}$ values from the

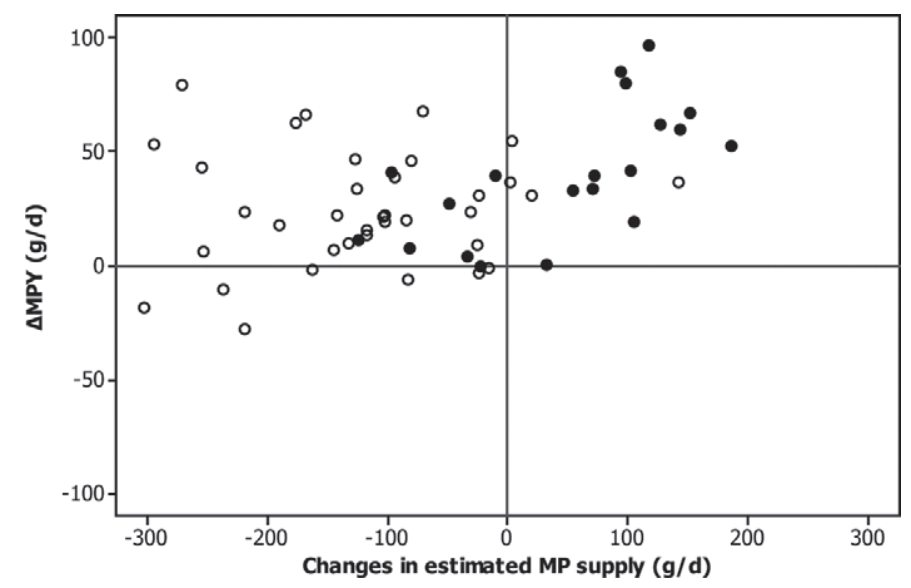

Figure 2. Relationship between responses in milk protein yield $(\triangle \mathrm{MPY}=$ canola meal diet minus control diet; $\mathrm{g} / \mathrm{d})$ and changes in MP supply (g/d) estimated by NRC (2001) according to data used (-) in the current study versus all data $(-$ and $\bigcirc)$ used in the initial meta-analysis (Martineau et al., 2013). 
current study and the initial meta-analysis was examined (Figure 2). Two-thirds of the observations in the current study showed positive $\Delta \mathrm{MP}_{\text {supply }}$, whereas the majority of observations in experiments not reporting plasma AA concentrations had negative $\Delta \mathrm{MP}_{\text {supply }}$, despite a positive $\triangle \mathrm{MPY}$. Not surprisingly, all 7 experiments using treated $\mathrm{CM}$ yielded positive $\Delta \mathrm{MP}_{\text {supply }}$ because in situ parameters of CM were corrected to decrease ruminal CP degradability and increase RUP provision. Responses in MPY ranged from -0.6 to 96.6 $\mathrm{g} / \mathrm{d}$ and were highest for treated $(\mathrm{n}=7)$ compared with untreated CM ( $\mathrm{n}=14$; i.e., 59.4 vs. $30.2 \mathrm{~g} / \mathrm{d}$ ). Using a larger database, Huhtanen et al. (2011) reported a significant decrease in MPY in treated versus untreated CM-supplemented diets when $\mathrm{MP}_{\text {supply }}$ was used as an independent variable; however, the comparison was not significant when CP intake was used as an independent variable. Those authors reported that the chemical and physical treatments commonly used to reduce ruminal CP degradability do not result in expected improvements in protein supply to the small intestine, according to rumen metabolism and digesta flow studies.

In contrast to the positive effect of CM feeding on the plasma concentrations of most EAA, CM feeding increased only the digestible flows of Met and Thr, suggesting an overall underestimation of digestible flows of most individual EAA by NRC (2001). The effects on Met and Thr are likely related to the fact that CM was compared with SBM in 10 out of 21 experiments and that treated CM was used in 7 out of 21 experiments (Table 1). According to NRC (2001), CM is a better source of Met and Thr compared with SBM on a percentage of CP basis. The relative proportions of Met and Thr in CM and SBM (i.e., content in $\mathrm{CM}$ divided by content in SBM; \% of $\mathrm{CP}$ ) are 1.29 and 1.11 for Met and Thr, respectively, compared with 0.77 to 1.01 for the other EAA, except Trp. Note that coefficient of determination values were among the highest for the effect of CM feeding on plasma concentrations of Met and Thr (i.e., 48 and $49 \%$, respectively) compared with $37 \%$ or less for the other EAA, except Arg (Table 4), suggesting that it was the RUP fraction of CM that might have an effect on plasma concentrations of EAA. Canola meal feeding did not increase the digestive flows of most EAA but increased the plasma concentrations of all EAA, indicating that the estimations of $\mathrm{MP}_{\text {sup- }}$ ply and digestive flows of EAA by NRC (2001) might not be reliable. Because plasma EAA concentrations are direct measurements in contrast to estimations

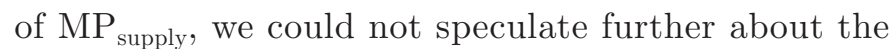
lack of agreement between both responses to $\mathrm{CM}$ feeding.

\section{CONCLUSIONS}

Canola meal feeding increased MY, MPY, MLY, and apparent $\mathrm{N}$ efficiency, but decreased BUN and MUN concentrations. These effects were associated with an increment in plasma concentrations of total AA, total EAA, BCAA, and all individual EAA. Together, these results indicate that $\mathrm{CM}$ feeding increased the absorption of all EAA despite the fact it increased only the digestible flows of Met and Thr as estimated by NRC (2001).

\section{ACKNOWLEDGMENTS}

Sincere thanks to the Canola Council of Canada (Winnipeg, MB, Canada) and Agriculture and AgriFood Canada (Sherbrooke, QC, Canada) for funding this research.

\section{REFERENCES}

Appuhamy, J. A. D. R. N., J. R. Knapp, O. Becvar, J. Escobar, and M. D. Hanigan. 2011. Effects of jugular-infused lysine, methionine, and branched-chain amino acids on milk protein synthesis in highproducing dairy cows. J. Dairy Sci. 94:1952-1960.

Baker, D. H. 1994. Utilization of precursors for L-amino acids. Pages 37-61 in Amino Acids in Farm Animal Nutrition. J. P. F. D'Mello, ed. CAB International, Wallingford, UK.

Bickerstaffe, R., E. F. Annison, and J. L. Linzell. 1974. The metabolism of glucose, acetate, lipids and amino acids in lactating dairy cows. J. Agric. Sci. 82:71-85.

Brito, A. F., G. A. Broderick, and S. M. Reynal. 2007. Effects of different protein supplements on omasal nutrient flow and microbial protein synthesis in lactating dairy cows. J. Dairy Sci. 90:18281841.

Broderick, G. A., P. Huhtanen, S. Ahvenjärvi, S. M. Reynal, and K. J. Shingfield. 2010. Quantifying ruminal nitrogen metabolism using the omasal sampling technique in cattle-A meta-analysis. J. Dairy Sci. 93:3216-3230.

Broderick, G. A., M. J. Stevenson, R. A. Patton, N. E. Lobos, and J. J. Olmos Colmenero. 2008. Effect of supplementing rumen-protected methionine on production and nitrogen excretion in lactating dairy cows. J. Dairy Sci. 91:1092-1102.

Burgos, S. A., M. Dai, and J. P. Cant. 2010. Nutrient availability and lactogenic hormones regulate mammary protein synthesis through the mammalian target of rapamycin signaling pathway. J. Dairy Sci. 93:153-161.

Cant, J. P., D. R. Trout, F. Qiao, and N. G. Purdie. 2002. Milk synthetic response of the bovine mammary gland to an increase in the local concentration of arterial glucose. J. Dairy Sci. 85:494-503.

Choi, C. W., and C. B. Choi. 2003. Flow of soluble non-ammonia nitrogen in the liquid phase of digesta entering the omasum of dairy cows given grass silage based diets. Asian-australas. J. Anim. Sci. 16:1460-1468.

Choi, C. W., A. Vanhatalo, S. Ahvenjärvi, and H. Huhtanen. 2002. Effects of several protein supplements on flow of soluble non-ammonia nitrogen from the forestomach and milk production in dairy cows. Anim. Feed Sci. Technol. 102:15-33.

Christen, K. A., D. J. Schingoethe, K. F. Kalscheur, A. R. Hippen, K. K. Karges, and M. L. Gibson. 2010. Response of lactating dairy cows to high protein distillers grains or 3 other protein supplements. J. Dairy Sci. 93:2095-2104.

Clark, J. H., T. H. Klusmeyer, and M. R. Cameron. 1992. Microbial protein synthesis and flows of nitrogen fractions to the duodenum of dairy cows. J. Dairy Sci. 75:2304-2323. 
Glasser, F., A. Ferlay, and Y. Chilliard. 2008. Oilseed lipid supplements and fatty acid composition of cow milk: A meta-analysis. J. Dairy Sci. 91:4687-4703.

Huhtanen, P., M. Hetta, and C. Swensson. 2011. Evaluation of canola meal as a protein supplement for dairy cows: A review and a metaanalysis. Can. J. Anim. Sci. 91:529-543.

INRA (Institut National de la Recherche Agronomique). 2007. INRAtion-Version professionnelle intégrale. 4.0 ed. Educagri éditions, Theix, France.

Laarveld, B., and D. A. Christensen. 1976. Rapeseed meal in complete feeds for dairy cows. J. Dairy Sci. 59:1929-1935.

Lapierre, H., C. E. Galindo, S. Lemosquet, I. Ortigues-Marty, L. Doepel, and D. R. Ouellet. 2010. Protein supply, glucose kinetics and milk yield in dairy cows. Pages 275-286 in Energy and Protein Metabolism and Nutrition. 3rd EAAP International Symposium on Energy and Protein Metabolism and Nutrition. G. Matteo Crovetto, ed. Wageningen Academic Publishers. Parma, Italy.

Martineau, R., D. R. Ouellet, and H. Lapierre. 2013. Feeding canola meal to dairy cows: A meta-analysis on lactational responses. J. Dairy Sci. 96:1701-1714.

Miettinen, H. O., and P. J. Huhtanen. 1997. Effects of silage fermentation and post-ruminal casein supplementation in lactating dairy cows: 2-Energy metabolites and plasma amino acids. J. Sci. Food Agric. 74:459-468

Miglior, F., A. Sewalem, J. Jamrozik, J. Bohmanova, D. M. Lefebvre, and R. K. Moore. 2007. Genetic analysis of milk urea nitrogen and lactose and their relationships with other production traits in Canadian Holstein cattle. J. Dairy Sci. 90:2468-2479.

Mulrooney, C. N., D. J. Schingoethe, K. F. Kalscheur, and A. R. Hippen. 2009. Canola meal replacing distillers grains with solubles for lactating dairy cows. J. Dairy Sci. 92:5669-5676.

Nousiainen, J., K. J. Shingfield, and P. Huhtanen. 2004. Evaluation of milk urea nitrogen as a diagnostic of protein feeding. J. Dairy Sci. $87: 386-398$.

NRC. 2001. Nutrient Requirements of Dairy Cattle. 7th rev. ed. National Academy of Sciences, Washington, DC.

Oba, M., G. B. Penner, T. D. Whyte, and K. Wierenga. 2010. Effects of feeding triticale dried distillers grains plus solubles as a nitrogen source on productivity of lactating dairy cows. J. Dairy Sci. 93:2044-2052.

Piepenbrink, M. S., and D. J. Schingoethe. 1998. Ruminal degradation, amino acid composition, and estimated intestinal digestibilities of four protein supplements. J. Dairy Sci. 81:454-461.
Piepenbrink, M. S., D. J. Schingoethe, M. J. Brouk, and G. A. Stegeman. 1998. Systems to evaluate the protein quality of diets fed to lactating cows. J. Dairy Sci. 81:1046-1061.

Pisulewski, P. M., H. Rulquin, J. L. Peyraud, and R. Verite. 1996. Lactational and systemic responses of dairy cows to postruminal infusions of increasing amounts of methionine. J. Dairy Sci. 79:1781-1791.

Raggio, G. 2006. Effet des apports protéique et énergétique sur le métabolisme protéique chez la vache laitière. $\mathrm{PhD}$ Thesis. Université Laval, Québec, QC, Canada.

Rinne, M., K. Kuoppala, S. Ahvenjärvi, and A. Vanhatalo. 2006. Rypsi soijaa parempi lypsylehmien valkuaistäydennys myös apilapitoista säilörehua syötettäessä. In Maataloustieteen päivät 2006. Suomen Maataloustieteellisen Tiedote 21:1-7. A. Hopponen, ed. Accessed Oct. 5, 2011. http://www.smts.fi/esit06/1002.pdf.

Sauvant, D., P. Schmidely, J. J. Daudin, and N. R. St-Pierre. 2008 Meta-analyses of experimental data: Application in animal nutrition. Animal 2:1203-1214.

Shingfield, K. J., A. Vanhatalo, and P. Huhtanen. 2003. Comparison of heat-treated rapeseed expeller and solvent-extracted soya-bean meal as protein supplements for dairy cows given grass silagebased diets. Anim. Sci. 77:305-317.

Sjaunja, L. O., L. Baevre, L. Junkkarinen, J. Pedersen, and J. Setälä. 1990. A Nordic proposal for an energy corrected milk (ECM) formula. Pages 156-157 in Proceedings of the 27th Session of the International Committee of Recording and Productivity of Milk Animal. EEAP Publication No. 50. P. Gaillon and Y. Chabert, ed. Pudoc, Wageningen, the Netherlands.

Vanhatalo, A., S. Ahvenjärvi, and S. Jaakkola. 2004. Metabolic and production responses in dairy cows fed peas or rapeseed meal on grass silage based diet. J. Anim. Feed Sci. 13:231-234.

Vanhatalo, A., E. Pahkala, and P. Salo-Väänänen. H. Korhonen, V. Piironen, and P. Huhtanen. 2003. Rapeseed and soybean as protein supplements of dairy cows fed grass silage based diets. Pages 1238-1240 in Proc. 11th Int. Rapeseed Congr.: Enhanced Value of Cruciferous Oilseed Crops by Optimal Production and Use of the High Quality Seed Components. H. Sørensen, S. Sørensen, N. Bellostas Muguerza, and C. Bjergegaard, ed. The Royal Veterinary and Agricultural University, Copenhagen, Denmark. 